\title{
ANALISIS PENGELOLAAN ASET TETAP DAERAH PADA DINAS PENGELOLAAN KEUANGAN ASET DAERAH (DPKAD) PROVINSI ACEH
}

\author{
Esduo Ramadhano Labasido * ${ }^{1}$, Darwanis ${ }^{* 2}$ \\ ${ }^{1,2}$ Program Studi Akuntansi Fakultas Ekonomi dan Bisnis Universitas Syiah Kuala \\ e-mail: esduoramadhanol@gmail.com ${ }^{* 1}$,darwanis.fe@unsyiah.ac.id ${ }^{* 2}$
}

\begin{abstract}
Abstrak
Fixed assets is one of the elements that must be managed properly in order to produce reliable information in the financial statements region. Orderly management of regional property (fixed assets) carries a significant effect on the perfection of regional balance sheet presentation. The purpose of this study to determine the suitability of fixed asset management at the Department of Finance and Asset Management Revenue Region (DPKAD) Aceh with Regulation of the Minister of the Interior 19 of 2016 visits from local property management cycle is applied as well as the completeness of the document source. The method used is a qualitative with descriptive analysis techniques. The results showed that DPPKAD Aceh as maid manager has implemented 10 cycles in the management of fixed assets. From 14 document source needed only 13 documents are there, so that the management of fixed assets in DPPKAD Aceh with Regulation 19 of 2016 has not been fully fit. Preferably, DPPKAD Aceh perform better coordination with all SKPDs as users/ parties responsible in making List of Regional Property Maintenance Requirements (DKPBMD) and List of Results Maintenance Goods as a form of compliance with applicable regulations.
\end{abstract}

Keywords: pengelolaan aset tetap, dokumen sumber.

\section{Pendahuluan}

\section{Latar Belakang}

Republik Indonesia merupakan negara kesatuan yang menganut asas desentralisasi dalam pemerintahan, dengan memberikan kesempatan dan keleluasaan kepada daerah untuk menyelenggarakan otonomi daerah (Rahardjo, 2014). Menurut UU No.32 Tahun 2004 desentralisasi didefinisikan penyerahan kewenangan dari pemerintah pusat kepada pemerintah daerah untuk mengurusi urusan rumah tangganya sendiri berdasarkan prakarsa dan aspirasi dari rakyatnya dalam kerangka negara kesatuan Republik Indonesia. Sedangkan otonomi daerah didefinisikan sebagai hak, wewenang, dan kewajiban daerah otonom untuk mengatur dan mengurus sendiri urusan pemerintahan dan kepentingan masyarakat setempat sesuai dengan peraturan perundang-undangan yang berlaku.

Pemberian kewenangan ini diwujudkan dengan pengaturan pembagian dan pemanfaatan sumber daya nasional serta perimbangan keuangan antara pemerintah pusat dengan pemerintah daerah. Suparmoko (2002) mengatakan otonomi daerah juga dapat mempercepat pertumbuhan ekonomi dan pembangunan daerah, serta mengurangi kesenjangan antar daerah. Pemberlakuan Undang-Undang Nomor 32 Tahun 2004 tersebut bukan hanya keinginan untuk melimpahkan kewenangan untuk pembangunan dari pemerintah pusat ke pemerintah daerah, tetapi yang lebih penting adalah pemerintah daerah dapat mengurus rumah tangganya sendiri secara professional dengan memanfaatkan sumber daya yang dimiliki oleh daerah tersebut dan mengelola keuangan daerah secara efisien dan efektif serta dapat menunjukkan akuntabilitas dan transparansi pada masyarakat daerah tersebut.

Salah satu bentuk pengelolaan yang dilakukan pemerintah daerah dalam rangka mengimplikasikan otonomi daerah tersebut ialah pengelolaan aset-aset yang dimiliki oleh pemerintah daerah. Menurut PSAP No.1 tahun 2010 mengartikan aset sebagai berikut :

Sumber daya ekonomi yang dikuasai dan/atau dimiliki oleh pemerintah sebagai akibat dari peristiwa masa lalu dan dari mana manfaat ekonomi dan/ atau sosial dimasa depan diharapkan dapat diperoleh, baik oleh pemerintah maupun masyarakat, serta dapat 
diukur dalam satuan uang, termasuk sumber daya nonkeuangan yang diperlukan untuk penyediaan jasa bagi masyarakat umum dan sumber-sumber daya yang dipelihara karena alasan sejarah dan budaya.

Saat ini aset merupakan salah satu permasalahan akuntansi yang masih banyak terdapat kendala atau kekurangan dalam penerapan akuntansinya, hal ini sesuai dengan pendapat Hines (1988) yang menyatakan bahwa "akuntansi untuk aset dalam beberapa hal terlihat memiliki kekurangan dibandingkan dengan akuntansi untuk aspek lainnya, mengingat sifat alamiah yang dimiliki oleh masingmasing aset tersebut. Dengan demikian pengelolaan aset daerah terutama pada aset tetap bukanlah perkara yang mudah, untuk itu pemerintah dituntut harus mengelola aset tetap yang dimiliki dengan sebaikbaiknya berdasarkan peraturan dan prinsip-prinsip yang berlaku. Pengelolaan aset tetap daerah menjadi salah satu hal penting dalam penyelenggaraan pemerintahan daerah saat ini dalam upaya menciptakan pemerintahan yang baik, efektif dan efisien serta penciptaan akuntabilitas publik. Secara yuridis pentingnya pengelolaan aset tetap daerah secara efisien, efektif, transparan dan akuntabel, tercantum dalam Peraturan Pemerintah Nomor 38 Tahun 2008 tentang Pengelolaan Barang Negara/Daerah, yang kemudian diatur pula dalam Permendagri Nomor 19 tahun 2016 tentang Pedoman Pengelolaan Barang Milik Daerah. Dengan adanya tuntutan dari publik serta perkembangan teknologi informasi yang begitu pesat maka pemerintah pun berupaya untuk melakukan perbaikan dalam pengelolaan aset tetap daerah. Dalam konteks tersebut, maka pengelolaan aset tetap daerah mulai berubah, dari cara-cara yang konvensional menuju sistem yang lebih canggih, yakni melalui penggunaan teknologi informasi dan komunikasi.

Berdasarkan Laporan Hasil Pemerikasaan Badan Pemeriksa Keuangan Republik Indonesia atas Laporan Keuangan Pemerintah Aceh TA 2014 di Banda Aceh masih terdapat masalah terhadap pengelolaan aset tetap Pemerintah Aceh yang mengakibatkan Provinsi Aceh mendapat predikat WDP (Wajar Dengan Pengecualian). Dalam LHP BPK No. 24.A/LHP/XVIII.BAC/07/2008 tanggal 28 Juli 2008 atas LKPD Pemerintah Aceh TA 2007, BPK mengecualiakan aset tetap karena terdapat perbedaan data antara Buku Induk Inventaris Daerah yang dijadikan dasar pencantuman angka aset tetap di neraca dengan data inventaris yang dimiliki oleh Bapelkes RSU Zainoel Abidin, Dinas Prasarana Wilayah, Dinas Peternakan, Dinas Sosial, Dinas Pendidikan, Bapelkes RS Ibu dan Anak dan Dinas Pertanian serta terdapat aset tetap sebesar Rp182.712.526.200,00 yang tidak dapat diyakini, baik keberadaan maupun nilainya. Pengecualian tersebut berlanjut sampai dengan TA 2012, sebagaimana diungkap dalam LHP BPK No. 20.A/LHP/XVIII.BAC/07/2013 tanggal 24 Juli 2013. Pada TA 2013, BPK mengecualikan aset tetap dalam LHP BPK No. 10.A/LHP/XVIII.BAC/05/2014 tanggal 21 Mei 2014, dikarenakan pengendalian intern pengelolaan aset tetap masih lemah, dimana terdapat selisih pencatatan antara Bidang Akuntansi dengan Kartu Inventaris Barang (KIB) SKPA yang belum dapat ditelusuri dan terdapat 152 item aset tetap yang bersaldo Rp0,00. Dalam LHP BPK No. 10.B/LHP/XVIII.BAC/05/2014 tanggal 21 mei 2014 tersebut, BPK mengungkapkan penatausahaan aset tetap TA 2013 belum memadai.

Hal ini tentunya menjadi tugas sekaligus tanggung jawab dari Dinas Pengeloaan Keuangan dan Aset Daerah (DPKAD) Provinsi Aceh yang sesuai dengan visi dan misinya. Visi dari DPKAD provinsi Aceh adalah terwujudnya kemampuan pengelolaan pendapatan, keuangan, dan aset yang transparan dan akuntabel, kemudian dituangkan dalam misi meningkatkan administrasi keuangan yang transparan dan akuntabel. Visi dan misi tersebut dilaksanakan dalam program Bidang Aset yaitu Pendataan Manajemen Aset Milik Daerah. DPKAD berkewajiban untuk menatausahakan seluruh Barang milik daerah (BMD) yang telah tercatat maupun pengadaan BMD baru pada setiap tahunnya

Penelitian mengenai pengelolaan aset daerah ini telah banyak dilakukan di Indonesia. Salah satu penelitian yang dilakukan di Indonesia oleh Kolinug, et.al (2015) menyimpulkan bahwa pengelolaan aset tetap oleh Bidang Aset pada DPPKAD Kota Tomohon telah mengikuti peraturan yang berlaku secara umum, seperti Permendagri No.17 Tahun 2007 tentang Pedoman Teknis Pengelolaan Barang Milik Daerah dan PP No.27 Tahun 2014 tentang Pengelolaan Barang Milik Negara/Daerah. Pada pelaksanaan siklus perencanaan dan penganggaran belum sepenuhnya sesuai karena ada dokumen DKPBMD yang tidak 
terhimpun oleh DPPKAD sebagai pembantu pengelola. Ini diakibatkan karena kurangnya koordinasi dan ketegasan dalam hal pelaporan dokumen tersebut. Pada pelaksanaan siklus penatausahaan, siklus pemanfaatan dan siklus pengamanan semua telah sesuai dengan Permendagri No.17 Tahun 2007 dengan adanya bukti-bukti dokumen fisik yang menyatakan semua sudah sesuai dengan prosedur yang ada. Tahap terakhir pada pelaksaan siklus penghapusan serta pemindahtanganan yang merupakan tindakan yang saling berhubungan juga telah sesuai dalam menghapus aset tetap yang tidak lagi optimal dalam penggunaannya dari daftar barang milik daerah.

Berbeda dengan Indonesia, penelitian mengenai aset tetap daerah tidak banyak dilakukan di negara lain. Negara yang berada di luar Indonesia cenderung lebih meneliti kepada interaksi fungsi organisasi. Seperti penelitian yang dilakukan Pike, et.al (2004) menyimpulkan tentang bagaimana pandangan kita mengenai sumber daya perusahaan agar kita dapat lebih memahami tentang konfigurasi strategis dari suatu organisasi terutama pada penggunaan navigator untuk membantu memahami interaksi dan dinamika antara aset berwujud dari suatu perusahaan.

Pada hakikatnya, semua penelitian yang telah disebutkan sebelumnya, merupakan upaya dalam memberikan hasil yang baik dan sesuai dengan prosedur dari pengelolaan aset tetap daerah atau aset tetap pada perusahaan yang berada di luar Indonesia. Hal inilah yang menjadi inti permasalahan dari penelitian ini. Oleh karena itu penelitian ini berfokus pada prosedur pengelolaan aset tetap daerah khususnya pada benda bergerak di Dinas Pengelolaan Keuangan dan Aset Daerah (DPKAD) Provinsi Aceh sebagai dinas yang memiliki kewajiban dalam melakukan prosedur akuntansi dari seluruh BMD yang dimiliki. Metode yang digunakan pada penelitian ini merupakan metode kualitatif dengan pendekatan studi kasus.

Berdasarkan uraian di atas fenomena yang telah dipaparkan sebelumnya, maka dengan ini peneliti akan melakukan sebuah penelitian dengan judul "Analisis Pengelolaan Aset Tetap Daerah Pada Dinas Pengelolaan Keuangan Aset Daerah (DPKAD) Provinsi Aceh".

\section{Rumusan Masalah}

Berdasarkan uraian latar belakang diatas, maka penulis dapat merumuskan permasalahan yang akan diangkat dalam penelitian ini, yaitu :

1. Bagaimana Pengelolaan Aset Tetap Daerah di Dinas Pengelolaan Keuangan dan Aset Daerah (DPKAD) Provinsi Aceh

2. Apakah Pengelolaan Aset Tetap Daerah di Dinas Pengelolaan Keuangan dan Aset Daerah (DPKAD) Provinsi Aceh sudah sesuai dengan Permendagri No.19 Tahun 2016

\section{Tujuan penelitian}

Adapun tujuan dari penelitian ini adalah sebagai berikut : Untuk mengetahui apakah pengelolaan aset tetap daerah di Dinas Pengelolaan Keuangan dan Aset Daerah (DPKAD) Provinsi Aceh sudah sesuai dengan prosedur yang ditetapkan oleh Permendagri No.19 Tahun 2016.

\section{Kegunaan Hasil Penelitian}

a. Dapat memberikan kontribusi pemikiran bagi disiplin ilmu Akuntansi, khususnya tentang Manajemen Aset .

b. Bagi Pemerintah Aceh agar dapat menjadikan hasil penelitian ini sebagai salah satu referensi dalam menentukan kebijakan pengelolaan aset tetap daerah guna meningkatkan Pendapatan Asli Daerah.

\section{Kegunaan Praktis}

Dapat dijadikan sebagai sumber referensi bagi peneliti/penulis lain yang hendak meneliti tentang Pengelolaan Aset Daerah.

\section{Kajian pustaka \\ Definisi Pengelolaan Aset Daerah}

Tidak sedikit yang mengartikan pengelolaan sama dengan arti manajemen. Karena antara manajemen dan pengelolaan memliliki tujuan yang sama yaitu tercapainya tujuan organisasi lembaga. Pengelolaan merupakan sebuah bentuk berkerja dengan orang-orang secara pribadi dan kelompok demi tercapainya tujuan organisasi lembaga (Siama, 2013).

Definisi manajemen sendiri memang tidak jauh berbeda dari pengelolaan namun, agar lebih jelas lagi berikut beberapa definisi tentang manajemen dari para ahli sebagai berikut : 
James A.F. Stoner (2006:organisasi.org) "Manajemen adalah suatu proses perencanaan, pengorganisasian, kepemimpinan, dan pengendalian upaya dari anggota organisasi serta penggunaan semua sumber daya yang ada pada organisasi untuk mencapai tujuan organisasi yang telah ditetapkan sebelumnya".

Ahli Mulayu S.P. Hasibuan (2000:2) "Manajemen adalah ilmu dan seni mengatur proses pemanfaatan sumber daya manusia dan sumbersumber lainnya secara efektif dan efisien untuk mencapai satu tujuan".

T. Hani Handoko (2000:10) "Manajemen adalah bekerja dengan orang-orang untuk menentukan, menginterpretasikan, dan mencapai tujuan-tujuan organisasi dengan pelaksanaan fungsi-fungsi perencanaan, pengorganisasian, penyusunan personalia, pengarahan, kepemimpinan, dan pengawasan".

Setelah mengetahui apa itu definisi dari pengelolaan atau manajemen kita juga perlu mengetahui apa definisi dari aset daerah itu sendiri. Aset menurut PSAP No.1 tahun 2010 mengartikan aset sebagai sumber daya ekonomi yang dikuasai dan/atau dimiliki oleh pemerintah sebagai akibat dari peristiwa masa lalu dan dari mana manfaat ekonomi dan/ atau sosial dimasa depan diharapkan dapat diperoleh, baik oleh pemerintah maupun masyarakat, serta dapat diukur dalam satuan uang, termasuk sumber daya nonkeuangan yang diperlukan untuk penyediaan jasa bagi masyarakat umum dan sumbersumber daya yang dipelihara karena alasan sejarah dan budaya. Dengan makna yang sama International Accounting Standard Committee (IASC) mengatakan bahwa aset sebagai sumber daya yang dikendalikan oleh suatu entitas sebagai hasil kejadian masa lalu yang mana manfaat ekonomis masa depan diharapkan didapatkan oleh perusahaan. Dalam statement of Accounting Concepts No. 4, Australian Accounting Standard Board (AASB) mendefinisikan aset sebagai sebagai potensial jasa atau manfaat ekonomis yang dikendalikan oleh pelaporan entitas sebagai hasil transaksi masa lalu. Sedangkan Kerangka Konseptual Akuntansi Pemerintah (Lampiran II PP No 24 tahun 2005) mendefinisikan asset lebih luas lagi, yaitu sebagai sumber daya ekonomi yang dikuasai dan atau dimiliki oleh suatu pemerintah sebagai akibat dari peristiwa masa lalu dan daripadanya diperoleh manfaat ekonomi baik oleh pemerintah maupun oleh masyarakat, dan dapat diukur dalam satuan uang, termasuk sumber daya non keuangan yang diperlukan untuk penyediaan jasa bagi masyarakat umum dan sumber daya yang dipelihara karena alasan sejarah dan budaya.

Di dalam Aset sendiri terdapat yang namanya Aset Daerah atau yang biasa disebut dengan Barang
Milik Daerah. Definisi dari Barang Milik Daerah itu sendiri menurut Permendagri No.17 Tahun 2007 tentang Pedoman Teknis Pengelolaan Barang Milik Daerah adalah "Semua barang yang dibeli atas beban Anggaran Pendapatan dan Belanja Daerah atau perolehan lainnya yang sah".

Dari semua definisi yang telah diuraikan diatas dapat ditarik kesimpulan bahwa pengelolaan aset daerah adalah Semua barang kekayaan daerah baik yang dibeli atau diperoleh atas beban Anggaran dan Pendapatan Belanja Daerah atau perolehan lainnya yang sah kemudian dikelola oleh suatu organisasi yang memiliki anggota untuk melakukan pengendalian guna mencapai tujuan organisasi lembaga yang telah ditetapkan sebelumnya.

\section{Karakteristik Aset Daerah}

Aset daerah banyak macamnya dan menurut peraturan pemerintah, aset pemerintah termasuk aset daerah terdiri atas enam golongan serta aset lainnya sebagai berikut "
1. Golongan Tanah
2. Golongan Peralatan dan Mesin
3. Golongan Gedung dan Bangunan
4. Golongan Jalan, Irigasi, dan Jaringan
5. Golongan Aset Tetap Lainnya
6. Golongan Konstruksi dalam Pengerjaan
7. Golongan Aset Lainnya

\section{1) Golongan Tanah}

Tanah merupakan aset pemerintah yang sangat vital dalam operasional pemerintahan dan pelayanan kepada masyarakat. Aset tanah merupakan aset yang paling sulit dalam pengelolaanya. Hal ini karena tanah milik pemerintah banyak ragamnya dengan status penggunaan yang juga bermacam-macam sehingga terjadi banyak kepentingan tanah-tanah yang dimiliki oleh pemerintah ataupun pemerintah daerah (Yusuf, 2010:13).

\section{2) Golongan Peralatan dan Mesin}

Peralatan dan mesin adalah aset yang sangat terkait dengan operasional internal pemerintahan, baik untuk operasional pemerintah pusat maupun pemerintah daerah, walaupun pemerintah daerah yang berperan dalam pengelolaannya (Yusuf, 2010:14). 


\section{3) Golongan Gedung dan Bangunan}

Gedung dan bangunan bagi suatu daerah merupakan alat yang paling penting karena pelayanan kepada masayarakat yang diberikan oleh pemerintah daerah banyak menggunakan gedung. Karakterisktik gedung yang dimiliki oleh pemerintah daerah antara lain bangunan tempat kerja, gudang, gedung laboratorium, bangunan rumah sakit, bangunan tempat pertemuan, bangunan tempat beribadah, bangunan gedung olahraga, gedung pertokoan, bangunan pos, bangunan garasi, bangunan kandang hewan, bangunan perpustakaan, bangunan museum, dan sebagainya (Yusuf, 2010:21).

\section{4) Golongan Jalan, Irigasi, dan Jaringan}

Penilaian terhadap kualitas jalan adalah suatu indikator bahwa infrastruktur di daerah tersebut baik dan bagus. Untuk memudahkan pengendalian terhadap kualitas jalan maka administrasi pengelolaan jalan harus bagus. Untuk melihat jalan apa saja yang perlu dicatat dalam aset pemerintah daerah, baik untuk pemerintah provinsi maupun untuk pemerintah daerah kabupaten/kota (Yusuf, 2010: 22).

Bangunan air merupakan suatu bentuk bangunan yang dapat menampung air dalam rangka pengambilan air untuk irigasi, saluran pembawa irigasi, bangunanbangunan seperti waduk, bangunan pengambilan irigasi meliputi bendungan, bangunan pembuang irigasi, dan bangunan pengamanan irigasi (Yusuf, 2010:22).
5) Golongan Aset Tetap Lainnya

Golongan aset ini jelas-jelas disebutkan dalam Permendagri No.19 Tahun 2016 yang terdiri atas buku perpustakaan, buku terbitan berkala, barang-barang perpustakaan, barang bercorak kesenian atau kebudayaan, serta hewan ternak da tumbuh-tumbuhan.

\section{6) Golongan Konstruksi dalam Pengerjaan}

Golongan barang ini dicatat sebesar biaya yang dikeluarkan sampai dengan akhir masa pengerjaan pada tahun yang bersangkutan. Golongan barang ini, seperti bangunan gedung dan bangunan bukan gedung, konstruksi jalan, jembatan, bangunan air, instalasi dan jaringan (Yusuf, 2010:23)

\section{7) Aset Lainnya}

Dalam Permendagri No.19 Tahun 2016 tidak dikenal adanya aset tidak berwujud berupa hasil kajian, kerja sama dengan pihak ketiga, serta aset-aset lainnya (Yusuf, 2010:23).

\section{Peneitian Terdahuu}

Penelitian mengenai pengelolaan aset tetap daerah telah banyak dilakukan di Indonesia maupun di luar Indonesia dengan hasil yang berbeda - beda. Ada beberapa penelitian yang menjadi referensi ataupun acuan dalam penulisan skripsi ini. Berikut tabel 2.2 menjelaskan mengenai penelitian - penelitian tersebut.

Tabel 2.2

Penelitian Terdahulu

\begin{tabular}{|c|c|c|c|c|}
\hline No & Peneliti & Judul Penelitian & Metode & Hasil \\
\hline 1. & $\begin{array}{l}\text { Mulalinda, dan } \\
\text { Tangkuman (2014) }\end{array}$ & $\begin{array}{l}\text { Evektivitas } \\
\text { Penerapan Sistem } \\
\text { dan Prosedur } \\
\text { Akuntansi Aset } \\
\text { Tetap Pada Dinas } \\
\text { Pendapatan, } \\
\text { Pengelolaan } \\
\text { Keuangan dan } \\
\text { Aset Daerah } \\
\text { Kabupaten Sitaro }\end{array}$ & Data primer & $\begin{array}{l}\text { Hasil penelitian ini menunjukkan } \\
\text { pelaksanaan proses sistem dan prosedur } \\
\text { aset/barang milik daerah pada Dinas } \\
\text { DPPKAD Kabupaten Sitaro pada setiap } \\
\text { subsistem belum efektif secara } \\
\text { keseluruhan. Hal ini terbukti dengan } \\
\text { masih adanya kelemahan pada bagian } \\
\text { sistem antara lain: pengadaan, } \\
\text { penggunaan, penyimpanan, pemanfaatan, } \\
\text { pemeliharaan, pengamanan dan } \\
\text { penghapusan. }\end{array}$ \\
\hline
\end{tabular}




\begin{tabular}{|c|c|c|c|c|}
\hline No & Peneliti & Judul Penelitian & Metode & Hasil \\
\hline 2. & $\begin{array}{l}\text { Kolinug, Ilat, dan } \\
\text { Pinatik (2015) }\end{array}$ & $\begin{array}{l}\text { Analisis } \\
\text { Pengeleloaan } \\
\text { Aset Tetap Pada } \\
\text { Dinas Pendapatan } \\
\text { Pengelolaan } \\
\text { Keuangan dan } \\
\text { Aset Daerah Kota } \\
\text { Tomohon }\end{array}$ & Data primer & $\begin{array}{l}\text { Kesimpulan dari penelitian ini adalah } \\
\text { 1. Pengelolaan aset tetap oleh bidang aset } \\
\text { pada DPPKAD Kota Tomohon sebagai } \\
\text { pembantu pengelola dilakukan dengan } \\
\text { berpedoman pada peraturan berlaku } \\
\text { umum, seperti Permendagri No. } 17 \text { Tahun } \\
\text { 2007 tentang Pedoman Teknis } \\
\text { Pengelolaan Barang } \\
\text { Negara/Daerah. } \\
\text { 2. Pelaksanaan siklus perencanaan dan } \\
\text { penganggaran belum sepenuhnya sesuai } \\
\text { karena ada dokumen DKPBMD yang } \\
\text { tidak terhimpun oleh DPPKAD sebagai } \\
\text { pembantu pengelola. Ini diakibatkan } \\
\text { karena kurangnya koordianasi dan } \\
\text { ketegasan dalam hal pelaporan dokumen } \\
\text { tersebut. } \\
\text { 3. Pelaksanaan siklus penatausahaan telah } \\
\text { sesuai dengan Permendagri No. } 17 \text { Tahun } \\
\text { 2007 dilihat dari berjalannya serangkaian } \\
\text { bentuk penatausahaan dan kelengkapan } \\
\text { dokumen yang ada untuk menunjang } \\
\text { pelaporan keuangan yang baik. } \\
\text { 4. Pelaksanaan siklus pemanfaatan telah } \\
\text { sesuai dengan Permendagri No. } 17 \text { Tahun } \\
\text { 2007 namun belum semua bentuk } \\
\text { pemanfaatan dilakukan. } \\
\text { 5. Pelaksanaan siklus pengamanan telah } \\
\text { sesuai dengan Permendagri No. } 17 \text { Tahun } \\
\text { 2007 dilihat dari adanya dokumen sumber } \\
\text { seperti bukti kepemilikan barang milik } \\
\text { daerah maupun upaya pengamanan yang } \\
\text { dilakukan oleh DPPKAD Kota Tomohon } \\
\text { dilihat dari tidak dilaporkannya } \\
\text { DKPBMD dan Daftar Hasil Pemeliharan } \\
\text { Barang Milik Daerah oleh SKPD/tidak } \\
\text { dihimpun oleh SKPD selaku pembntu } \\
\text { pengelola, dinyatakan belum sesuai } \\
\text { dengan Permendagri No. } 17 \text { Tahun } 2007 . \\
6 \text {. Pelaksanaan siklus penghapusan serta } \\
\text { pemindahtanganan yang merupakan } \\
\text { tindakan yang saling berhubungan telah } \\
\text { sesuai dalam menghapus aset tetap yang } \\
\text { tidak lagi optimal dalam penggunaannya } \\
\text { dari daftar barang milik daerah. }\end{array}$ \\
\hline
\end{tabular}




\begin{tabular}{|c|c|c|c|c|}
\hline No & Peneliti & Judul Penelitian & Metode & Hasil \\
\hline 3 & $\begin{array}{l}\text { Erizul dan Yuliani } \\
\text { (2014) }\end{array}$ & $\begin{array}{l}\text { Pelaksanaan } \\
\text { Pengelolaan Aset } \\
\text { Tetap Daerah }\end{array}$ & Data Primer & $\begin{array}{l}\text { Hasil penelitian ini menunjukan bahwa } \\
\text { pelaksanaan pengelolaan aset tetap daerah } \\
\text { milik Dinas Pendapatan, Pengelolaan } \\
\text { Keuangan dan Aset Kabupaten Kampar } \\
\text { dalam melakukan koordinasi pengelolaan } \\
\text { aset tetap daerah yang ditinjau dari } \\
\text { akuntabilitas kinerja belum optimal, } \\
\text { masih banyak terdapat tidak sinkronnya } \\
\text { nilai aset, inventaris dan sistim pelaporan } \\
\text { dan pengendalian yang belum baik. } \\
\text { Dikarenakan perencanaan pengadaan } \\
\text { barang tidak sesuai dengan kebutuhan } \\
\text { unit kerja dan ketersediaan dana yang } \\
\text { terbatas sebagai akibat kurangnya } \\
\text { perhatian pimpinan dalam menyusulkan } \\
\text { anggaran dalam pengadaan aset daerah } \\
\text { untuk mendukung operasional di setiap } \\
\text { SKPD. Disamping itu kurang adanya } \\
\text { penyesuaian pelaksanaan pengadaan } \\
\text { barang dengan ketentuan yang berlaku } \\
\text { karena pengadaan masih kurang } \\
\text { memperhatikan kesesuaian harga barang, } \\
\text { dan pengadaan aset daerah mash } \\
\text { cenderung membeli dengan penujukan } \\
\text { langsung, pendistribusian barang relatif } \\
\text { masih kurang merata ke setiap SKPD. }\end{array}$ \\
\hline 4. & $\begin{array}{l}\text { Pike, Roos dan Marr } \\
(2005)\end{array}$ & $\begin{array}{l}\text { Strategic } \\
\text { Management of } \\
\text { Intangible Assets } \\
\text { and Value } \\
\text { Drivers in R\&D } \\
\text { Organizations }\end{array}$ & Data primer & $\begin{array}{l}\text { Penelitian yang disajikan dalam tulisan } \\
\text { ini menggambarkan bagaimana sumber } \\
\text { daya berdasarkan pandangan dari } \\
\text { perusahaan untuk dapat lebih membuat } \\
\text { kita paham tentang konfigurasi strategis } \\
\text { organisasi. Khususnya penggunaan } \\
\text { navigator membantu untuk saling } \\
\text { memahami saling mempengaruhi dan } \\
\text { dinamisme antar aset tidak berwujud } \\
\text { sebuah perusahaan. Ini memberikan bukti } \\
\text { yang mendukung untuk teori-teori } \\
\text { sebelumnya tentang pentingnya aset tidak } \\
\text { berwujud dalam resiko dan } \\
\text { pengembangan proses penciptaan nilai } \\
\text { dan khususnya tentang sifat dinamis dari } \\
\text { aset - aset ini. }\end{array}$ \\
\hline 5 & $\begin{array}{l}\text { Gardberg dan } \\
\text { Fombrun (2006) }\end{array}$ & $\begin{array}{l}\text { Corporate } \\
\text { Citizenship: } \\
\text { Creating } \\
\text { Intangible Assets } \\
\text { Across } \\
\text { Institutional } \\
\text { Environments }\end{array}$ & Data primer & $\begin{array}{l}\text { Kesimpulannya, kewarganegaraan } \\
\text { korporasi menyediakan aplikasi strategis } \\
\text { keseimbangan teori yang sesuai. Pada } \\
\text { jantung perusahaan - perusahaan yang } \\
\text { mengglobal terpecah antara eksploitasi } \\
\text { kompetensi inti di pasar dan legitimasi } \\
\text { bangunan di seluruh kelembagaan } \\
\text { lingkungan. }\end{array}$ \\
\hline
\end{tabular}




\begin{tabular}{|c|c|c|c|c|}
\hline No & Peneliti & Judul Penelitian & Metode & Hasil \\
\hline 6 & Lev dan Daum (2004) & $\begin{array}{l}\text { The Dominance } \\
\text { of Intangible } \\
\text { Assets : } \\
\text { Consequences for } \\
\text { Enterprise } \\
\text { Management and } \\
\text { Corporate } \\
\text { Reporting }\end{array}$ & Data primer & $\begin{array}{l}\text { Berdasarkan hasil regresi, produktivitas } \\
\text { merupakan prioritas utama bangsa - } \\
\text { bangsa dan badan usaha. Peningkatan } \\
\text { produktivitas sumber daya adalah } \\
\text { pendorong utama kesejahteraan bangsa - } \\
\text { bangsa (standar hidup, pekerjaan), } \\
\text { keuntungan perusahaan dan nilai } \\
\text { pemegang saham. Tetapi produktivitas } \\
\text { manajemen dan optimisasi, seperti } \\
\text { banyak orang yang percaya tidak dimulai } \\
\text { dengan penilaian individu. Pada } \\
\text { kenyataanya semua itu harus dimulai } \\
\text { dengan pemahaman tentang wujud } \\
\text { peranan dalam keseluruhan sistem } \\
\text { penciptaan nilai organisasi. Dengan } \\
\text { demikian, infrastruktur organisasi } \\
\text { perusahaan berfungsi sebagai penyedia } \\
\text { nilai tambah dari masukan sumber daya. } \\
\text { Aset berwujud dan tidak berwujud } \\
\text { menjadi faktor kritis perusahaan. }\end{array}$ \\
\hline
\end{tabular}

Sumber : Data diolah 2016

\section{Hasil Penelitian}

Untuk dapat memahami pokok permasalahan dari penelitian, peneliti membuat kerangka pikir atau model penalaran tentang proses pengelolaan aset tetap berdasarkan Permendagri terbaru No.17 Tahun 2007 Pasal 4 Ayat 2 seperti yang digambarkan pada gambar 2.1 .

Gambar 2.1

Kerangka Pemikiran

\begin{tabular}{|c|}
\hline Pengelolaan Aset tetap Daerah Pada \\
DPKAD Aceh \\
\hline \\
\hline $\begin{array}{c}\text { Siklus Pengelolaan Aset Tetap Daerah } \\
\text { Sesuai Dengan Permendagri No.19 Tahun } \\
2016\end{array}$ \\
\hline $\begin{array}{c}\text { Pengelolaan Aset Tetap Daerah yang Baik } \\
\text { dan Efisien }\end{array}$ \\
\hline
\end{tabular}

\section{Metode Penelitian}

\section{Desain Penelitian}

Desain penelitian bagaikan sebuah peta jalan bagi peneliti yang menuntun dan menentukan arah berlangsungnya proses penelitian secara benar dan tepat sesuai dengan tujuan yang telah ditetapkan
(Sarwono, 2008:79). Desain penelitian adalah semua proses yang diperlukan dalam perencanaan dan pelaksanaan penelitian, mulai tahap persiapan sampai tahap penyusunan laporan (Nazir, 2013:11). Penelitian ini merupakan sebuah penelitian dengan metode kualitatif, Menurut Herdiansyah (2010:9) penelitian kualitatif adalah suatu penelitian yang bertujuan untuk memahami suatu fenomena dalam konteks sosial secara alamiah dengan mengedepankan proses interaksi komunikasi yang mendalam antara peneliti dengan fenomena yang diteliti.

Tujuan studi terbagi atas; eksploratif, deskriptif, dan pengujian hipotesis (Sekaran, 2009:155). Dalam penelitian ini tujuan studinya adalah deskriptif yaitu menjelaskan dan meringkas berbagai kondisi dan variabel yang dijadikan sebagai objek penelitian berdasarkan pada kenyataan yang terjadi di lapangan. Adapun tujuan studi deskriptif adalah memberikan kepada peneliti sebuah riwayat atau untuk aspek-aspek yang relevan dengan menggambarkan fenomena dari organisasi atau lainnya (Sekaran, 2009:158). Jenis Studi yang digunakan dalam penelitian ini adalah studi kasus. Studi kasus merupakan suatu model penelitian kualitatif yang terperinci tentang individu atau suatu unit sosial dalam kurun waktu tertentu. Secara lebih mendalam studi kasus merupakan suatu model yang bersifat komprehensif, intens, terperinci dan mendalam serta lebih diarahkan sebagai upaya untuk menelaah 
masalah-masalah atau fenomena yang bersifat kontemporer/berbatas waktu (Herdiansyah, 2010:9)..

\section{Objek dan Subjek penelitian}

Objek penelitian ini adalah Aset Tetap yang ada pada Dinas Pengelolaan Keuangan dan Aset Daerah (DPKAD) Provinsi Aceh, alasan pemilihan objek tersebut adalah karena Dinas Pengelolaan Keuangan dan Aset Daerah (DPKAD) Provinsi Aceh merupakan salah satu SKPD di Aceh. Selain itu Dinas Pengelolaan Keuangan dan Aset Daerah (DPKAD) Provinsi Aceh juga merupakan pengelola seluruh aset SKPD yang berada di aceh, jadi diharapkan pengelolaan aset tetap yang berada di Dinas Pengelolaan Keuangan dan Aset Daerah (DPKAD) Provinsi Aceh tersebut juga sudah mengikuti standar yang ditetapkan oleh pemerintah, baik dari segi pengadaan, pemeliharaan maupun juga kontribusinya dalam laporan keuangan daerah. Dinas Pengelolaan Keuangan dan Aset Daerah (DPKAD) Provinsi Aceh diharapkan mempunyai tata kelola yang lebih baik dibanding dengan SKPD lain di Aceh. Oleh karena itu Dinas Pengelolaan Keuangan dan Aset Daerah (DPKAD) Provinsi Aceh dianggap cocok untuk dijadikan setting penelitian dalam hal perlakuan akuntansinya.

\section{Sumber Data}

Sumber data penelitian merupakan faktor yang menjadi pertimbangan dalam metode pengumpulan data, dimana sumber data dapat berupa data primer dan data sekunder (Indriantoro, 1999:146). Data Primer, yaitu data-data penelitian yang diperoleh secara langsung dan berasal dari hasil pengamatan langsung terhadap objek yang diteliti. Data yang digunakan dalam penelitian ini adalah data gabungan antara data primer dan data sekunder. Data primer diperoleh berupa hasil wawancara dengan beberapa informan yang terkait, seperti kepala bidang aset DPKAD, kepala dinas DPKAD, serta Informan lain yang terkait. Sedangkan Data Sekunder berupa Annual Report atau dokumen-dokumen terkait mengenai pengelolaan Aset Tetap Daerah.

\section{Teknik Pengumpulan Data}

Teknik pengumpulan data dalam suatu penelitian kualitatif dapat dilakukan dengan cara observasi, kuesioner dan wawancara (Sugiyono, 2007:137). Berikut penjelasan masing-masing teknik pengumpulan data pada peneltian ini:

\section{Wawancara}

Sebagian besar penelitian ini menggunakan teknik wawancara dalam mengumpulkan data. Dalam metode wawancara (interview), data dikumpulkan dengan mengajukan sejumlah pertanyaan secara lisan untuk dijawab secara lisan pula. Ciri utama dari wawancara adalah adanya kontak langsung antara si pencari informasi (Interviewer) dengan sumber informasi (Interviewee) (Sutopo, 2006:74). Wawancara dilakukan dengan menggunakan teknik wawancara mendalam berupa wawancara semi struktur, yaitu wawancara yang pelaksanannya lebih bebas daripada terstruktur atau fleksibel, pertanyaan yang diajukan tergantung pada partisipan yang akan diwawancarai (Sugiyono, 2012: 73-74).

Untuk memastikan bahwa semua pertanyaan penelitian dapat diungkap dan proses wawancara berjalan sesuai alur, maka peneliti membuat hubungan antara pertanyaan penelitian, sumber dan teknik pengumpulan data, serta justifikasi pada tabel 3.1.

Tabel 3.1

Hubungan antara Pertanyaan Penelitian, Sumber dan Teknik Pengumpulan Data, Serta Justifikasi

\begin{tabular}{|c|c|c|c|}
\hline No & Pertanyaan & $\begin{array}{l}\text { Sumber dan Teknik } \\
\text { Pengumpulan Data }\end{array}$ & Justifikasi \\
\hline 1 & $\begin{array}{l}\text { Bagaimana proses } \\
\text { pelaksanaan sistem dan } \\
\text { prosedur pengelolaan Aset } \\
\text { Tetap Daerah pada DPKAD } \\
\text { Provinsi Aceh? }\end{array}$ & $\begin{array}{l}\text { Sumber: } \\
\text { 1. Kepala DPKAD } \\
\text { 2. Kepala Bidang Aset } \\
\text { Teknik Pengumpulan Data } \\
\text { - Wawancara } \\
\text { - Dokumentasi }\end{array}$ & $\begin{array}{l}\text { Pertanyaan tersebut merupakan pertanyaan inti } \\
\text { yang harus diungkap. Untuk itu, dalam } \\
\text { mengungkap hal ini peneliti memilh Kepala } \\
\text { DPKAD dan Kepala Bidang Aset sebagai } \\
\text { informan. Peneliti menggunakan teknik } \\
\text { pengambilan data wawancara dan dokumentasi } \\
\text { dalam melaksanakan penelitian ini. }\end{array}$ \\
\hline
\end{tabular}




\begin{tabular}{|c|c|c|c|}
\hline No & Pertanyaan & $\begin{array}{l}\text { Sumber dan Teknik } \\
\text { Pengumpulan Data }\end{array}$ & Justifikasi \\
\hline 2 & $\begin{array}{l}\text { Apakah DPKAD Provinsi } \\
\text { Aceh memiliki pengawasan } \\
\text { khusus dalam pengelolaan } \\
\text { Aset Tetap Daerah? }\end{array}$ & $\begin{array}{l}\text { Sumber : } \\
\text { 1. Kepala DPKAD } \\
\text { 2. Kepala Bidang Aset } \\
\text { Teknik Pengumpulan Data } \\
\text { - Wawancara } \\
\text { - Dokumentasi }\end{array}$ & $\begin{array}{l}\text { Upaya pengelolaan aset yang baik sebaiknya } \\
\text { juga didukung oleh pengawasan yang baik, dan } \\
\text { sistem pengawasan yang baik pasti diketahui } \\
\text { dan dipahami oleh informan. Peneliti } \\
\text { menggunakan teknik pengambilan data } \\
\text { wawancara dan dokumentasi dalam } \\
\text { melaksanakan penelitian ini. }\end{array}$ \\
\hline 3 & $\begin{array}{l}\text { Apakah ada kendala-kendala } \\
\text { yang dihadapi dalam } \\
\text { pengelolaan Aset Tetap } \\
\text { Daerah di DPKAD Provinsi } \\
\text { Aceh? }\end{array}$ & $\begin{array}{l}\text { Sumber: } \\
\text { 1. Kepala DPKAD } \\
\text { 2. Kepala Bidang Aset } \\
\text { Teknik Pengumpulan Data } \\
\text { - Wawancara } \\
\text { - Dokumentasi }\end{array}$ & $\begin{array}{l}\text { Kendala yang dihadapi tentu dirasakan oleh } \\
\text { para pelaksana teknis, untuk mengungkap } \\
\text { kendala tersebut dipilihlah beberapa sumber } \\
\text { informan tersebut. Peneliti menggunakan } \\
\text { teknik pengambilan data wawancara dan } \\
\text { dokumentasi dalam melaksanakan penelitian } \\
\text { ini. }\end{array}$ \\
\hline
\end{tabular}

\section{Dokumentasi}

Penelitian ini menggunakan metode dokumentasi sebagai data sekunder yang digunakan sebagai penunjang dari data primer yang ada. Dalam metode ini peneliti diharapkan dapat membaca, memahami, menganalisis serta mengkritisi dokumendokumen yang ada. Selain itu dalam studi dokumentasi ini, informasi juga bisa diperoleh lewat fakta yang tersimpan dalam bentuk catatan, arsip dan lain sebagainya yang diperoleh dari organisasi tersebut (Blaxter et al., 2001:251-252). Dokumen yang diperlukan dalam penelitian ini berupa Annual report, arsip dan dokumen lainnya yang diperoleh dari dinas terkait mengenai objek penelitian.

\section{Metode Analisis data}

Analisis data menurut Sugiyono (2009: 244) adalah "proses mencari dan menyusun secara sistematis data yang diperoleh dari hasil wawancara, catatan lapangan, dan bahan-bahan lain, sehingga dapat mudah dipahami, dan temuannya dapat diinformasikan kepada orang lain. Dalam proses menganalisis data dengan teknik wawancara langkah pertama yang harus dilakukan adalah merepresentasikan data (suara) yang diperoleh dari hasil wawancara dengan media (voice recorder) yang digunakan menjadi sebuah data berbentuk tulisan atau transkrip (Bailey, 2008). Setelah data telah ditranskripsikan barulah proses analisis lainya dilakukan seperti; pengelompokan data berdasarkan hal-hal pokok/tema penelitian (coding), menginterpretasikan data dengan teori dan referensi lain, kemudian mendeskripsikan/menyajikan data, serta menarik kesimpulan (Smith \& Osborn, 2008). O,Connor \& Gibson (2003) juga menambahkan proses analisis data kualitatif meliputi langkah-langkah seperti; organizing the data, finding and organizing ideas and concepts, building overarching themes in the data, ensuring reliability and validity in the data analysis and in the findings, finding possible and plausible explanations for findings, an overview of the final steps. Adapun langkah- langkah yang akan dilakukan dalam penelitian ini sebagai berikut:

1. Membuat transkrip wawancara atau menulis ulang seluruh hasil wawancara yang didapat dari proses perekaman wawancara dengan informan.

2. Mengelompokkan data atau memisahkan antara beberapa siklus pengelolaan aset daerah.

3. Mengidentifikasi dan menganalisis data yang diperoleh.

4. Menginterpretasikan data tersebut dengan teori, literatur dan standar akuntansi yang ada.

5. Mendeskripsikan bagaimana masing-masing siklus pengelolaan aset tetap pada Dinas Pengelolaan Keuangan Aset Daerah (DPKAD) Provinsi Aceh.

6. Menarik kesimpulan dari data yang telah diproses sebelumnya tentang pengelolaan aset tetap pada Dinas Pengelolaan Keuangan Aset Daerah (DPKAD) Provinsi Aceh, dan melakukan verifikasi pada informan mengenai kesimpulan tersebut. 
Langkah-langkah tersebut dilakukan sesuai dengan metode analisis yang dianjurkan oleh Miles dan Huberman (1994) dalam (Sugiyono, 2009:211) yaitu:

\section{Reduksi data (Data Reduction)}

Reduksi data merupakan proses pemilihan, pemusatan perhatian, pengabstrakan dan pentranformasian data kasar dari lapangan. Fungsinya untuk menajamkan, mengarahkan, membuang yang tidak perlu, menggolongkan, dan mengorganisasi sehingga interpretasi dapat ditarik. Data yang diperoleh dari proses wawancara nantinya akan diseleksi dan diorganisir melalui teknik pengkodean (coding) dan tulisan ringkas. Dalam mereduksi data, data yang tidak relevan dipisahkan dari data yang relevan dengan penelitian. Jadi, data yang digunakan diharapkan benar-benar data yang valid.

\section{Penyajian data (data display)}

Pada tahap ini, peneliti mengembangkan sebuah deskripsi informasi tersusun untuk menarik kesimpulan dan pengambilan tindakan. Penyajian data yang lazim digunakan dalam penelitian ini adalah bentuk teks naratif. Maksud dari teks naratif ialah peneliti mendeskripsikan informasi yang telah diklasifikasikan sebelumnya mengenai perlakuan akuntansi untuk aset bersejarah, yang kemudian dibentuk simpulan dan selanjutnya simpulan tersebut disajikan dalam bentuk teks naratif.

3. Menarik kesimpulan atau verifikasi

Penarikan kesimpulan atau verifikasi merupakan kegiatan di akhir penelitian. Peneliti harus sampai pada kesimpulan dan melakukan verifikasi, baik itu dari segi makna maupun dari segi kebenaran kesimpulan yang disepakati oleh subjek tempat penelitian tersebut dilaksanakan. Makna yang dirumuskan dari data harus diuji terlebih dahulu mengenai kebenaran, kecocokan dan kekokohannya. Peneliti harus menyadari bahwa dalam mencari makna, peneliti tersebut harus menggunakan pendekatan emik, yaitu dari Narasumber dan bukan penafsiran makna menurut pandangan peneliti

\section{Hasil dan Pembahasan Gambaran Objek Penelitian Provinsi Aceh}

Aceh adalah sebuah provinsi di Indonesia. Aceh terletak di ujung utara pulau Sumatera dan merupakan provinsi paling barat di Indonesia. Ibu kotanya adalah Banda Aceh. Jumlah penduduk provinsi ini sekitar 4.500.000 jiwa. Letaknya dekat dengan Kepulauan Andaman dan Nikobar di India dan terpisahkan oleh Laut Andaman. Aceh berbatasan dengan Teluk Benggala di sebelah utara, $\underline{\text { Samudra }}$ Hindia di sebelah barat, Selat Malaka di sebelah timur, dan Sumatera Utara di sebelah tenggara dan selatan.

Aceh dianggap sebagai tempat dimulainya penyebaran Islam di Indonesia dan memainkan peran penting dalam penyebaran Islam di Asia Tenggara. Pada awal abad ke-17, Kesultanan

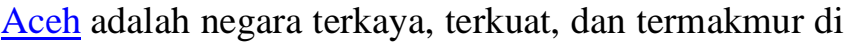
kawasan Selat Malaka. Sejarah Aceh diwarnai oleh kebebasan politik dan penolakan keras terhadap kendali orang asing, termasuk bekas penjajah Belanda dan pemerintah Indonesia. Jika dibandingkan dengan dengan provinsi lainnya, Aceh adalah wilayah yang sangat konservatif (menjunjung tinggi nilai agama). Persentase penduduk Muslimnya adalah yang tertinggi di Indonesia dan mereka hidup sesuai syariah Islam. Berbeda dengan kebanyakan provinsi lain di Indonesia, Aceh memiliki otonomi yang diatur tersendiri karena alasan sejarah.

Aceh memiliki sumber daya alam yang melimpah, termasuk minyak bumi dan gas alam. Sejumlah analis memperkirakan cadangan gas alam Aceh adalah yang terbesar di dunia. Aceh juga terkenal dengan hutannya yang terletak di sepanjang jajaran Bukit Barisan dari Kutacane di Aceh Tenggara sampai Ulu Masen di Aceh Jaya. Sebuah taman nasional bernama Taman Nasional Gunung Leuser (TNGL) didirikan di Aceh Tenggara.

Aceh adalah daratan yang paling dekat dengan episentrum gempa bumi Samudra Hindia 2004. Setelah gempa, gelombang tsunami menerjang sebagian besar pesisir barat provinsi ini. Sekitar 170.000 orang tewas atau hilang akibat bencana tersebut. Bencana ini juga mendorong terciptanya perjanjian damai antara pemerintah Republik Indonesia dan Gerakan Aceh Merdeka (GAM). 


\section{Dinas Pengelolaan Keuangan dan Aset Daerah Provinsi Aceh}

Dinas Pengelolaan Keuangan dan Aset Daerah Provinsi Aceh merupakan salah satu SKPD yang melakukan fungsi Satuan Kerja Pengelola Keuangan (SKPKD) termasuk didalamnya aset tetap bertugas sebagai pembantu pengelola yang melakukan koordinasi, penyelenggaraan, evaluasi, pelaporan dan pengadministrasian dalam hal penghimpunan berbagai laporan yang dihasilkan dari semua SKPD sebagai pengguna barang dan menyampaikannya kepada Sekretaris Daerah sebagai Pengelola.

Pengelolaan aset tetap pada Dinas Pengelolaan Keuangan dan Aset Daerah Provinsi Aceh dikelola oleh Bidang Penatausahaan Aset yang mempunyai tugas melakukan perencanaan, penganggaran, pengadaan, penggunaan ,pemanfaatan, pemeliharaan, penatausahaan, penilaian, penghapusan, pemindahtanganan, pengamanan dan pengelolaan asset daerah.

Untuk melaksanakan tugas , Bidang Penatausahaan Aset mempunyai fungsi:

1. Perumusan rancangan kebijakan teknis di bidang pengelolan aset yang meliputi perencanaan, penganggaran, pengadaan, penggunaan, pemanfaatan, pemeliharaan, penatausahaan, penilaian, penghapusan, pemindahtanganan dan pengamanan aset daerah;

2. Penyusunan program kerja di bidang pengelolan aset yang meliputi perencanaan, penganggaran, pengadaan, penggunaan, pemanfaatan, pemeliharaan, penatausahaan, penilaian, penghapusan, pemindahtanganan dan pengamanan aset daerah;

3. Pelaksanaan pengelolaan aset yang meliputi perencanaan, penganggaran, pengadaan, penggunaan, pemanfaatan, pemeliharaan, penatausahaan, penilaian, penghapusan, pemindahtanganan dan pengamanan asset daerah;

4. Pengumpulan dan pengolahan data aset daerah;

5. Pelaksanaan koordinasi dengan instansi dan atau lembaga terkait lainnya di bidang aset dan kekayaan daerah; dan

6. Pelaksanaan tugas-tugas kedinasan lainnya yang diberikan oleh Kepala Dinas Pendapatan dan Kekayaan Aceh sesuai dengan tugas dan fungsinya.

Bidang Penatausahaan Aset, terdiri dari:

- Seksi Perencanaan kebutuhan aset;

- Seksi Inventerisasi dan Penilaian; dan

- Seksi Pemanfaatan dan Pemindahtangan.

Masing-masing Seksi dipimpin oleh seorang Kepala Seksi yang berada di bawah dan bertanggung jawab kepada Kepala Bidang Penatausahaan Aset sesuai dengan bidang tugasnya.

1. Seksi Perencanaan Kebutuhan Asset mempunyai tugas melakukan penyusunan standar harga barang, rencana kebutuhan barang, standar kebutuhan barang, rencana pengadaan barang dan penyaluran proses penyaluran dan penetapan status barang dana otsus.

2. Seksi Inventarisasi dan Penilaian mempunyai tugas menghimpun laporan buku inventaris barang daerah, menyimpan barang inventaris berupa Buku Kepemilikan Kendaraan Bermotor, melakukan penyusunan buku laporan barang milik daerah, melakukan penilaian terhadap barang inventaris daerah yang telah idle, dan yang sudah tidak mempunyai nilai ekonomis untuk diusulkan penghapusan, melakukan pelaksanaan penjualan barang inventaris daerah dan mengusulkan penetapan status pengguna barang milik Pemerintah Aceh.; dan

3. Seksi Pemanfaatan dan Pemindahtanganan mempunyai tugas melakukan penatausahaan sewa menyewa, pinjam pakai, BGS dan BSG, serta pemindahtanganan seperti penjualan tukarmenukar, hibah dan penyertaan modal.

\section{Pembahasan Data Hasil Penelitian}

\section{Siklus Pengelolaan Aset Tetap DPKAD Provinsi Aceh}

Siklus pengelolaan aset tetap adalah rangkaian kegiatan dari proses pengelolaan aset tetap yang merupakan tindakan konkret terhadap daerah dibawah kontrol Peraturan Pemerintah Pusat dalam hal ini Peraturan Menteri Dalam Negeri No.19 Tahun 2016. Tugas pokok dan fungsi yang wajib dilakukan oleh Bidang Penatausahaan Aset adalah mengusahakan tertibnya administrasi pengelolaan aset tetap serta bertindak sebagai Pembantu Pengelola. Permendagri No. 19 Tahun 2016 menyatakan ada siklus yang harus diilalui dalam pengelolaan tetap yang melibatkan DPKAD sebagai pembantu pengelola. Pembantu 
pengelola adalah unit kerja yang membantu pengelola (Sekretaris Daerah) untuk meneliti, menghimpun laporan bahkan menjadi penyelenggara dalam pelaksanaan tahapan pengelolaan barang milik daerah. Dibawah ini akan dijelaskan mengenai teknis pelaksanaan siklus pengelolaan aset tetap berdasarkan Permendagri No.19 Tahun 2016 serta prosedur yang dilakukan oleh DPKAD Provinsi Aceh, dalam hal ini Bidang Penatausahaan Aset sebagai Pembantu Pengelola.

1. Perencanaan Kebutuhan dan Penganggaran Pada siklus ini Satuan Kerja Perangkat Daerah sebagai pengguna barang merencanakan dan menyusun kebutuhan barang dalam Rencana Kerja dan Anggaran Satuan Kerja Perangkat Daerah (RKA-SKPD) sebagai bahan dalam penyusunan Rencana Anggaran Pendapatan dan Belanja Daerah (RAPBD), kemudian masingmasing SKPD menyusun Rencana Kebutuhan Barang dan Rencana Kebutuhan Pemeliharaan Barang dalam bentuk usulan kemudian menyampaikan kepada Pengelola melalui pembantu pengelola. Pembantu pengelola menghimpun usulan RKBMD dan RKPBMD untuk diteliti namun tidak disusun menjadi dokumen Rencana Daftar Kebutuhan Barang Milik Daerah (RDKBMD) dan Rencana Kebutuhan Pemeliharaan Barang Milik Daerah (RKPBMD). Dari usulan RKBMD, ketika dihasilkan Dokumen Pelaksanaan Anggaran (DPA), langsung menjadi Daftar Kebutuhan Barang (DKB) dan tidak diproses lagi menjadi dokumen DKBMD. Hal ini dikuatkan oleh pernyataan dari hasil wawancara peneliti dengan Kasubid penatausahaan aset yang mengatakan "Perencanaan kebutuhan dan penganggaran sudah sesuai dengan peraturan, karena ini memang dasar dari pengelolaan".

2. Pengadaan

Siklus pengadaan seperti yang dijelaskan pada Permendagri No.19 Tahun 2016, bahwa pengadaan barang milik daerah dilaksanakan berdasarkan prinsip-prinsip efisien, efektif, transparan dan terbuka, bersaing, adil/tidak diskriminatif dan akuntabel. Permendagri No.19 Tahun 2016 Pasal 41 juga menyatakan bahwa pengadaan barang atau jasa pemerintah daerah dilaksanakan sesuai peraturan perundang- undangan. Seperti yang dikatakan oleh Kasubid penatausahaan aset DPKAD Aceh, beliau mengatakan "Memang sudah sesuai dengan Permendagri No.19 Tahun 2016, karena kan pengadaan ini kita mengacu kepada peraturan perundang-undangan yang ada terkait peraturan pengadaan barang dan jasa". Berdasarkan pernyataan tersebut maka siklus pengadaan pada pengelolaan aset tetap DPKAD Aceh memang sudah sesuai dengan Permendagri No.19 Tahun 2016.

3. Penggunaan

Permendagri No.19 Tahun 2016 sebagai dasar pengelolaan aset tetap menjelaskan bahwa siklus penggunaan yang tertera pada Pasal 43 sampai Pasal 77 merupakan siklus yang apabila Barang Milik Daerah telah ditetapkan status penggunaannya maka aset tetap tersebut digunakan untuk penyelenggaraan tugas dan fungsi pokok SKPD dan dapat juga dioperasikan oleh pihak lain dalam rangka mendukung pelayanan umum sesuai dengan tugas pokok dan fungsi SKPD yang bersangkutan. Apabila SKPD menggunakan aset tetap tersebut tidak sesuai dengan tugas pokok dan fungsi SKPD, maka akan dicabut status penggunaannya dan dapat dialihkan kepada SKPD lainnya. Dalam sikus penggunaan ini, tanggung jawab dalam pengelolaan aset tetap merupakan wewenang pada masing-masing SKPD.

Sesuai dengan hasil wawancara peneliti, Kasubid penatausahaan Aset DPKAD Aceh juga mengatakan hal yang sama. Dalam wawancara tesebut beliau mengatakan "Dalam tahap ini kan setelah kami menerima aset tetap tadi, Kepala SKPD kami mengajukan untuk menetapkan status penggunaan barangnya ke kepala daerah untuk ditetapkan dasar penetapan status penggunaan barang dan dasar itu untuk dicatat di kartu inventaris barang. Dasar status itu dikeluarkan melalui SK Gubernur untuk SKPD kami sehingga barang itu memang dibawah kewenangan dan tanggung jawab kami pengelolaannya". Dapat disimpulkan bahwa tahap penggunaan dalam pengelolaan aset tetap di DPKAD masih sesuai dengan Permendagri No.19 Tahun 2016. 
4. Penatausahaan

Permendagri No.19 Tahun 2016 Pasal 474 sampai 479 menejelaskan bahwa siklus penatausahaan terbagi menjadi 3 (tiga) bagian yaitu, pembukuan, inventarisasi, dan pelaporan. Pada bagian pembukuan pengguna barang melakukan pendaftaran dan pencatatan barang milik daerah ke dalam Daftar Barang Pengguna (DPB) atau Daftar Barang Kuasa Pengguna (DBKP) menurut penggolongan dan kodefikasi barang yang kemudian dimuat dalam Kartu Inventaris Barang A, B, C, D, E dan F. Selanjutnya, pada bagian inventarisasi pengelola dan pengguna melaksanakan sensus barang milik daerah setiap 5 (lima) tahun sekali untuk menyusun Buku Inventaris dan Buku Induk Inventaris beserta rekapitulasi barang milik pemerintah daerah. Pada bagian terakhir yaitu bagian pelaporan pengguna barang melakukan penyusunan laporan barang semesteran dan tahunan dengan tujuan untuk disampaikan kepada Kepala Daerah melalui pembantu pengelola. Pembantu pengelola menghimpun laporan tersebut menjadi Laporan Barang Milik Daerah (LBMD) yang difungsikan sebagai bahan untuk menyusun neraca Pemerintah Daerah.

DPKAD Aceh melalui Kasubid penatausahaan aset juga menyampaikan hal yang serupa, berdasarkan hasil wawancara peneliti beliau mengatakan "Tahap ini merupakan tahap penyusunan laporan keuangan yaitu penyusunan neraca, dimana ditahap ini dilakukan pembukuan, pencatatan dan pelpaoran, yang melakukakannya itu seksi pentausahaan. Tahap ini kan nanti ada KIB A, B, C, D sampai F kan dan itu semua ada di neraca karena memang semua komposisi aset tetap itu ada di neraca". Ini membuktikan bahwa pengelolaan aset tetap di DPKAD Aceh untuk siklus penatausahaan telah mengikuti Permendagri No.19 Tahun 2016.

5. Pemanfaatan

Permendagri No.19 Tahun 2016 Pasal 78 sampai Pasal 298 menjelaskan bahwa pemanfaatan adalah barang milik daerah yang berupa tanah dan/atau bangunan, selain tanah dan/atau bangunan yang digunakan untuk menunjang tugas pokok dan fungsi SKPD yang dilaksanakan oleh pengguna setelah mendapat persetujuan oleh kepala daerah. Selain itu pemanfaatan barang milik daerah berupa tanah dan/atau bangunan, selain tanah dan/atau bangunan yang tidak digunakan untuk menunjang tugas pokok dan fungsi SKPD dapat dipergunakan untuk kepentingan lain setelah pengelola atau pengguna mendapat persetujuan dari kepala daerah. Dari penjelasan diatas dapat dilihat bahwa barang milik daerah yang tidak digunakan untuk menunjang tugas pokok dan fungsi SKPD dapat dimanfaatkan untuk kepentingan lain, sehingga dalam Permendagri No.19 Tahun 2016 pun dijelaskan apa yang dimaksud dengan digunakan untuk kepentingan lain tersebut.

Pada Permendagri No.19 Tahun 2016 disebutkan dan dijelaskan bahwa bentuk pemanfaatan barang milik daerah yang tidak dipergunakan untuk menunjang tugas pokok dan fungsi SKPD dibagi menjadi 4 (empat) bentuk pemanfaatan, yaitu :
a. Sewa;
b. Pinjam Pakai;
c. Kerjasama Pemanfaatan; dan
d. Bangun Guna Serah dan Bangun Serah Guna Dalam Permendagri No.19 Tahun 2016 dijelaskan bahwa bentuk pemanfaatan berupa sewa, barang milik daerah baik barang bergerak maupun barang tidak bergerak yang belum dimanfaatkan oleh pemerintah daerah, dapat disewakan kepada pihak ketiga sepanjang menguntungkan daerah. Barang milik daerah yang disewa tersebut tidak merubah status dari kepemilikannya serta penyewaan barang milik daerah berupa tanah dan/atau bangunan dilakukan oleh pengelola setelah mendapat persetujuan dari kepala daerah. Jangka waktu penyewaan dilakukan paling lama 5 (lima) tahun dan dapat diperpanjang serta dilakukan berdarkan surat perjanjian sewa-menyewa serta hasil penerimaan sewa disetor ke kas daerah.

Bagian pemanfaatan kedua adalah pinjam pakai, dijelaskan dalam Permendagri No.19 Tahun 2016 barang milik daerah berupa tanah dan/atau bangunan, selain tanah dan/atau bangunan dapat dipinjampakaikan untuk kepentingan penyelenggaraan pemerintah daerah. Penyelenggaraan pinjam pakai dapat dilaksanakan oleh pengelola setelah mendapatkan persetujuan dari kepala daerah dengan jangka waktu pinjam pakai barang milik daerah paling lama 2 (dua) 
tahun dan dapat diperpanjang serta melakukan penandatanganan surat perjanjian pinjam pakai.

Pada bagian pemanfaatan yang ketiga yaitu kerjasama pemanfaatan, Permendagri No.19 Tahun 2016 menjelaskan bahwa pelaksaanaan kerjasama pemanfaatan dengan pihak lain dilaksanakan dalam rangka mengoptimalkan daya guna dan hasil guna barang milik daerah serta untuk meningkatkan penerimaan daerah. Permendagri No.19 Tahun 2016 menjelaskan bahwa kerjasama pemanfaatan dilaksanakan dengan ketentuan tidak tersedia dan/atau tidak cukup tersedia dana dalam APBD untuk memenuhi biaya operasional/pemeliharaan/perbaikan yang perlu dilakukan untuk barang milik daerah tersebut. Kerjasama pemanfaatan menetapkan mitra kerjasamanya melalu tender atau lelang dengan mengikutsertakan minimal 5 (lima) peserta atau peminat. Dalam hal besaran pembayaran kontribusi tetap dan pembagian keuntungan hasil kerjasama pemanfaatan ditetapkan oleh hasil perhitungan tim yang ditetapkan oleh kepala daerah dan disetor ke kas daerah setiap tahunnya selama jangka waktu pengoperasiannya yang disebutkan paling lama 30 (tiga puluh) tahun dan dapat diperpanjang jika sudah habis.

Bagian pemanfaatan yang terakhir yaitu bangun guna serah dan bangun serah guna juga dijelaskan dalam Permendagri No.19 Tahun 2016. Bangun guna serah dan bangun serah guna dilaksanakan apabila pemerintah daerah memerlukan bangunan dan fasilitas bagi penyelenggaraan pemerintahan daerah untuk kepentingan pelayanan umum dalam rangka penyelenggaraan tugas pokok dan fungsi. Bagian pemanfaatan yang terakhir ini dilaksanakan oleh pengelola apabila telah mendapat persetujuan dari kepala daerah serta kepala daerah telah menerima tanah yang diserahkan oleh pengguna kepada kepala daerah tersebut.

Berdasarkan Penjelasan Permendagri No.19 Tahun 2016 tersebut, peneliti juga menemukan penjelasan serupa dari hasil wawancara dengan Kasubid penatausahaan aset DPKAD Aceh yang mengatakan "nah ini dasarnya dari penetapan status yang kepala daerah buat pas tahap penggunaan, misalnya pada dinas A ada 5 (lima) aset tanah, yang 3 (tiga) digunakan untuk tugas pokok fungsi, 2 (dua) lagi misalnya tidak digunakan, nah si pengguna barang ini harus melaporkannya kepada pengelola, nanti si pengelola ini kan dalam hal ini DPKAD kan bisa mengkoordinir aset-aset tersebut, nanti pengelola liat mana dinas yang memerlukan tanah misalnya, bisa dialokasikan ke dinas tersebut atau bisa saja tanah-tanah tersebut yang tidak dipakai untuk tugas pokok fungsi tadi disewakan, karena pemanfaatan ini kan ada 4 (empat), bisa disewakan, di pinjam pakai, di kerjasamakan sama di $B G S$ atau $B S G$ nah itu maksud dari pemanfaatan untuk di daya guna usahakan lah. Kalau di sewakan, SKPD ini kan mengkoordinir dan uang sewanya itu masuk ke kas daerah tapi masuknya melalui SKPD ini. Kenapa melalui SKPD ini ? Karena kan aset yang tidak digunakan sama SKPD ini tadi jadi tanggung jawab si SKPD ini, tapi dia tetap harus melaporkannya ke pengelola, sama juga hal nya dengan pemanfaatan yang 3 (tiga) lagi sisanya tadi, pengguna dalam hal ini SKPD wajib lapor ke pengelola untuk setiap pemanfaatan yang dilakukan sama masingmasing SKPD. Kalau untuk DPKAD sendiri, kalau melakukan pemanfaatan tadi udah pasti ikutin peraturan, karena SKPD yang lain aja wajib lapor ke kami udah sesuai apa belum, masa kami sendiri gak sesuai". Pernyataan Kasubid penatausahaan aset DPKAD aceh tersebut menguatkan argumen peneliti bahwa siklus pemanfaatan yang dilakukan oleh DPKAD Aceh sudah sesuai dengan Permendagri No.19 Tahun 2016.

6. Pengamanan dan Pemeliharaan

Siklus Pengamanan dan pemeliharaan merupakan hal yang sangat urgent dalam pengelolaan aset, karena kalau siklus ini pengelolaannya sedikit lemah saja dapat berakibat fatal untuk aset-aset yang dimiliki oleh SKPD. Permendagri No.19 Tahun 2016 Pasal 296 sampai Pasal 324 menjelaskan bahwa pengelola, pengguna dan/atau kuasa pengguna wajib melakukan pengamanan barang milik daerah yang berada dalam penguasaannya. Pengamanan barang milik daerah itu sendiri meliputi pengamanan administrasi yang didalamnya ada kegiatan pembukuan, inventarisasi, pelaporan dan penyimpanan 
dokumen kepemilikan. Kemudian pengamanan fisik untuk mencegah terjadinya penurunan fungsi barang, penurunan jumlah barang, dan hilangnya barang. Pengamanan fisik untuk tanah juga dilakukan dengan cara pemagaran dan pemasangan tanda batas, untuk selain tanah dan bangunan dilakukan dengan cara penyimpanan dan pemeliharaan. Terakhir, melakukan pengamanan hukum dengan melengkapi bukti status kepemilikan.

Pemeliharaan wajib dilakukan oleh pembantu pengelola, pengguna dan/atau kuasa pengguna atas barang milik daerah yang dibawah kekuasaannya. Pemeliharaan haruslah berpedoman pada Daftar Kebutuhan Pemeliharaan Barang Milik Daerah (DKPBMD) serta biaya atas pemeliharaan barang milik daerah dibebankan

pada Anggaran Pendapatan dan Belanja Daerah. Dalam hal ini, Kasubid penatausahaan Aset DPKAD Aceh mengungkapkan bahwa masih ada kendala yang dihadapi dalam siklus ini, beliau mengatakan "dengan adanya penetapan status tadi itu oleh kepala daerah artinya kan barang-barang aset tadi itu yang telah diberikan kepada masingmasing SKPD harus diamankan, misal tanah ada berapa hektar apakah sudah ada sertifikat ? sudah ada batas plang ? mana yang punya warga dan mana yang punya pemerintah. Kalau sudah ada sertifikatnya it's oke tidak masalah, nah ini kalau misalnya ada tanah yang tidak ada sertifikatnya, jangankan sertifikatnya mungkin batas-batasnya saja tidak tau dimana. Nah, itukan bisa saja suatu saat memunculkan suatu kejadian yang tidak diinginkan, entah hilang atau karena diserobot oleh pihak ketiga makanya disinalah dilakukan pengamanan tadi, kalau pemeliharaan kan lebih ke peralatan dan mesin. Namun, pengamanan dan pemeliharaan ini harus ada dasarnya dulu, nah dasarnya itu adalah penetapan status tadi oleh kepala daerah dan sudah tercatat di kartu inventaris barang".

Kemudian peneliti kembali bertanya kepada Kasubid penatausahaan DPKAD Aceh tentang masalah yang sebenaranya pada siklus ini, karena menurut peneliti pada siklus ini sering terjadi kesalahan pengelolaan terhadap aset-aset tetap pada pemerintah. Kasubid penatausahaan aset
DPKAD Aceh pun menjelaskan, beliau mengatakan "pengamanan dan pemeliharaan ini dulu kan peraturannya belum terlalu kuat, kalau tidak salah ini munculnya tahun 2005 tentang pengelolaan keuangan. Sebelum tahun 2005 kalau saya tidak salah kan masih pake undang-undang, jadinya kan peraturannya belum tertib, belum kuat dan belum akuntabel, jadi pada saat itu juga belum adanya tertib administrasi aset sehingga itu dia mengapa sering terjadi masalah disini. Akhirnya 2005 keatas mulai lah timbul upayaupaya untuk memperpaikinya dengan mengeluarkan peraturan khusus tentang pengelolaan ini. Makanya dulu sering terjadi aset hilang, aset diserobot oleh pihak ketiga karena dasar tertib administrasinya belum kuat".

Peneliti pun kembali bertanya, apakah saat ini masalah di siklus ini masih sering terjadi dengan sudah baiknya peraturan yang sudah berlaku. Kasubid penatausahaan aset DPKAD Aceh pun mengatakan " memang masih ada, karena kan kami sekarang disuruh untuk menertibkan masalah-masalah yang lalu itu, terus kami juga harus menelusuri dokumen-dokumen kebelakang itu kan susah, sehingga masih ada aset-aset yang memang milik Pemerintah Aceh dan tercatat di kartu inventaris barang namun tidak diketahui keberadaanya. Makanya saat penyusunan laporan keuangan Pemerintah Aceh, predikat yang didapat masih WDP yaa karena itu tadi masalahnya".

Berdasarkan hasil wawancara tersebut dapat diambil kesimpulan bahwa DPKAD Aceh dalam siklus penglolaan aset tetapnya tahap pengamanan dan pemeliharaan memang sudah mengikuti Permendagri No.19 Tahun 2016 namun, karena adanya masalah-masalah terdahulu dalam pengelolaan aset tetap mengakibatkan DPKAD Aceh harus menelisik ulang semua dokumen yang ada guna dapat memberikan LKPA yang baik dan sesuai.

7. Penilaian

Siklus penilaian adalah siklus yang dilakukan guna menyususn neraca Pemerintah Daerah. Sesuai dengan penjelasan pada Permendagri No.19 Tahun 2016 BAB IX, Pasal 325 sampai 328 yang menjelaskan bahwa siklus penilaian dilakukan untuk menyusun neraca Pemerintah Daerah, pemanfaatan dan pemindahtanganan barang milik daerah. Dalam melakukan penilaian 
barang milik daerah, Kepala Daerah telah menetapkan tim khusus untuk melakukan penilaian dan bisa juga melibatkan penilai independen yang bersertifikat di bidang aset. Dalam melakukan penetapan nilai guna menyusun neraca Pemerintah Daerah dalam Permendagri No.19 Tahun 2016 dikatakan haruslah sesuai dengan Standar Akuntansi Pemerintahan (SAP) yang berlaku.

DPKAD Aceh selaku pembantu Kepala Daerah yang bertugas mengelola Aset Tetap milik Pemerintah Aceh juga sudah melakukan siklus penilaian ini, berdasarkan hasil wawancara peneliti dengan Kasubid penatausahaan aset DPKAD Aceh, beliau mengatakan "penilaian ini kan tujuannya ada 3 (tiga), penilaian aset untuk mendapatkan nilai wajar yang tujuannya untuk dimanfaatkan, kayak misalnya sewa kan, artinya untuk mendapatkan nilai wajar ini ada pihak ketiga, ada investor luar yang ikut serta dan dua lagi untuk penyusunan laporan keuangan yang disini neraca dan terakhir untuk pemindahtanganan. Intinya penilaian disini digunakan untuk 3 (tiga) hal tadi itu aja. Kalau ditanya udah sesuai apa belum dengan peraturan ya pasti udah sesuai, kan dari masing-masing kegunaan penilaian tadi ada tata caranya lagi, kami selaku pengelola ya berpedoman pada tata cara itu".

Berdasarkan wawancara tersebut peneliti dapat menyimpulkan bahwa DPKAD Aceh selaku pembantu Kepala Daerah sudah mengikuti dan sesuai dengan dasar aturan yang ada yaitu Permendagri No.19 Tahun 2016.

8. Penghapusan

Permendagri No.19 Tahun 2016 sebagai dasar acuan dalam mengelola aset tetap pemerintah daerah menjelaskan bahwa siklus penghapusan meliputi penghapusan dari daftar barang pengguna dan/atau kuasa pengguna dimana penghapusan ini dilakukan apabila barang milik daerah tersebut sudah tidak berada dalam penguasaan pengguna dan/atau kuasa pengguna. Selain itu penghapusan juga dilakukan dari daftar barang milik daerah apabila barang milik daerah tersebut sudah beralih kepemilikannya, terjadi pemusnahan atau karena sebab-sebab lainnya. Permendagri No.19 Tahun 2016 Pasal 450 juga menjelaskan bahwa Penghapusan barang milik daerah dengan tindak lanjut pemusnahan dilakukan apabila barang milik daerah tidak dapat digunakan, tidak dapat dimanfaatkan dan tidak dapat dipindahtangankan atau alasan lain sesuai ketentuan peraturan perundang-undangan.
Berdasarkan hasil wawancara peneliti dengan Kasubid penatausahaan aset DPKAD Aceh, beliau juga mengatakan hal yang serupa, yaitu "dasar penghapusan itu ya tadi kayak force mager yang artinya ini penghapusan dari pencatatan atau penghapusan dari daftar barang milik daerah kan. Karena ini force mager dan biasanya itu berdampak pada bangunan atau gedung maka harus didokumentasikan dulu sebelum dirobohkan karena nanti auditor juga pasti bertanya kenapa ini dirobohkan atau dihapuskan. Jadi dengan adanya dokumentasi ini mulai dari sebelum dirobohkan, saat dirobohkan sampai rata dengan tanah barulah bisa diusulkan hapus ke Gubernur, nanti Gubernur mengeluarkan izin prinsip bahwa boleh dihapus, setelah keluar izin prinsip itu barulah kami bisa menghapus aset tersebut dari pencatatan karena sudah ada dasarnya".

Kutipan wawancara tersebut membuat peneliti dapat menarik kesimpulan bahwa DPKAD Aceh memang telah mengikuti aturan yang ada karena DPKAD Aceh memang sudah pernah melakukan siklus penghapusan ini terutama pada saat Tsunami Aceh 2004 silam.

9. Pemindahtanganan

Permendagri No.19 Tahun 2016 sebagai dasar acuan dalam pengelolaan aset tetap daerah menjelaskan bahwa tahap pemindahtanganan dapat dilakukan apabila barang milik daerah sudah rusak dan tidak dapat dipergunakan kemudian dihapus dari daftar inventaris barang milik daerah yang pelaksanaannya sesuai dengan ketentuan perundang-undangan. Barang milik daerah yang dihapus namun masih memiliki nilai ekonomis, dapat dilakukan melalui pelelangan umum/pelelangan terbatas atau disumbangkan maupun dihibahkan kepada pihak lain. Dalam tahap ini terdapat bentuk-bentuk pemindahtanagan sebagai tindak lanjut atas penghapusan barang milik daerah yaitu penjualan, tukar menukar, hibah dan penyertaan modal pemerintah daerah.

Penjelasan serupa dalam tahapan ini juga disampaikan oleh Kasubid penatausahaan aset DPKAD Aceh melalui wawancara dengan peneliti, beliau menyampaikan "pemindahtanganan itu apa saja ? kan ada hibah, jual, penyertaan modal, terakhir tukar guling. Pemindahtanganan itu sendiri adalah peralihan kepemilikan apakah dalam bentuk hibah, penjualan, penyertaan modal atau tukar menukar itu tadi. Dalam pemindahtanganan, tahapan penilaian cuma digunakan pada jual, penyertaan modal dan tukar guling, kalau hibah tidak perlu 
adanya penilaian untuk nilai wajarnya, tapi cukup untuk nilai perolehannya saja. Jadi intinya penilaian itu diperlukan untuk pemanfaatan, untuk pemindahtanganan dan untuk penyusunan laporan keuangan. Kalau barang milik daerah sudah dilakukan pemindahtanganan, maka kami selaku pengelola wajib menghapusnya dari daftar inventaris barang milik daerah".

Berdasarkan hasil wawancara peneliti dengan Kasubid penatausahaan aset DPKAD Aceh, peneliti dapat menarik kesimpulan bahwa DPKAD Aceh selaku pengelola aset daerah dalam tahapan pemindahtangan sudah mengikuti aturan yang berlaku yaitu Permendagri No.19 Tahun 2016 karena DPKAD Aceh sendiri sudah sering melakukan tahapan ini sebelumya.

10. Pembinaan, pengawasan dan pengendalian

Tahapan ini dalam pengelolaan aset tetap daerah juga dijelaskan dalam Permendagri No.19 Tahun 2016 Pasal 480 sampai Pasal 483 dimana Menteri Dalam Negeri melakukan pembinaan pengelolaan barang milik daerah kemudian Kepala Daerah melakukan pengendalian pengelolaan barang milik daerah. Selanjutnya pengguna barang melakukan pemantauan dan penertiban terhadap penggunaan, pemanfaatan, pemindahtanganan, penatausahaan, pemeliharaan, dan pengamanan barang milik daerah yang berada di bawah penguasaannya. Dalam pelaksanaan pemantauan dan penertiban itu dilaksanakan oleh Pengguna. Pengguna dan kuasa pengguna barang dapat meminta aparat pengawas fungsional untuk melakukan audit tindak lanjut hasil pemantauan dan penertiban yang selanjutnya pengguna dan kuasa pengguna barang menindaklanjuti hasil audit sesuai ketentuan perundangundangan.

Dalam tahapan ini Permendagri No.19 Tahun 2016 Pasal 483 juga menjelaskan bahwa pengelola berwenang untuk melakukan pemantauan dan investigasi atas pelaksanaan penggunaan, pemanfaatan, dan pemindahtanganan barang milik daerah, dalam rangka penertiban penggunaan, pemanfaatan, dan pemindahtanganan barang milik daerah sesuai ketentuan yang berlaku.

Kasubid penatausahaan aset DPKAD Aceh melalui wawancara dengan peneliti juga menyampaikan bahwa "pembinaan itu sendiri adalah kita memberikan pemahaman, sosialisasi ke semua SKPA yang ada tentang bagaimana pengelolaan barang, kemudian penyusunan ketentuan terkait pengelolaan barang di daerah sesuai dengan Perda yang berlaku sedangkan kalo pengawasan dan pengendalian misalnya ada asetaset yang dimanfaatkan oleh pihak ketiga dalam arti kata disini disewa. Kalau untuk pengawasan dari tahap awal pengelolaan itu balik lagi kepada SKPA masing-masing dan memang ada orang khusus yang ditunjuk oleh DPKAD Aceh untuk melakukan tugas tersebut. Pembinaan, pemgawasan dan pengendalian itu sendiri harus mengacu kepada Permendagri No.19 Tahun 2016 itu tadi karena pada dasarnya Mendagri yang melakukan keseluruhan pembinaan pada aset tetap daerah yang setelah itu kepala daerah melakukan pengendalian pengelolaan aset tetap daerah yang dibantu ya sama kami ini DPKAD Aceh".

Berdasarkan hasil wawancara tersebut peneliti dapat menarik kesimpulan bahwa DPKAD Aceh selaku pembantu kepala daerah dalam melakukan pengelolaan aset tetap daerah sudah melakukan tahapan pembinaan, pengawasan dan pengendelian sesuai dengan Permendagri No.19 Tahun 2016.

11. Pemusnahan

Permendagri No.19 Tahun 2016 Pasal 421 sampai Pasal 423 menjelaskan bahwa pemusnahan barang milik daerah dilakukan apabila BMD tersebut tidak dapat digunakan, tidak dapat dimanfaatkan, dan/atau tidak dapat dipindahtangankan serta terdapat alas an lain sesuai dengan ketentuan peraturan perundangundangan. Pemusnahan tersebut dilaksanakan oleh Pengguna Barang setelah mendapat persetujuan Gubernur/Bupati/Walikota dan dituangkan ke dalam berita acara untuk dilaporkan kepada Gubernur/Bupati/walikota

Kasubid penatausahaan aset DPKAD Aceh juga menerangkan dalan wawancaranya dengan peneliti, beliau mengatakan "pemusnahan itu dilakukan apabila BMD sudah tidak mempunyai nilai ekonomis lagi namun, dalam melakukan pemusnahan harus ada dasarnya dulu kenapa BMD tersebut dimusnahkan dan harus ada persetujuan dulu dari gubernur boleh tidak BMD ini dimusnahkan.

Peneliti dapat menarik kesimpulan berdasarkan hasil wawancara diatas bahwa DPKAD Provinsi Aceh selaku pengelola telah melaksanakan tugasnya dalam tahap pemusnahan sesuai dengan peraturan yang berlaku yaitu Permendagri No.19 Tahun 2016.

12. Pengelolaan BMD Pada SKPD yang Menggunakan Pola Penggunaan Keuangan BLUD Permendagri No.19 Tahun 2016 menjelaskan bahwa Barang milik daerah yang digunakan oleh Badan Layanan Umum Daerah merupakan kekayaan daerah yang tidak dipisahkan untuk 
menyelenggarakan kegiatan Badan Layanan Umum Daerah yang bersangkutan.

Kasubid penatasusahaan aset DPKAD Aceh melalui wawancaranya dengan peneliti mengakatan bahwa " ini seperti rumah sakit, kan asetnya dia dibawah kewenangan pengelolaan SKPD yang pengeloaan-pengeloaannya melalui BLUD, jadi dirumah sakit itu kan ada asetasetnya dan memang kewenangannya itu dibawah BLUD. Memang aset itu didapat dari APBA namun mereka punya kewenangan sendiri dalam melakukan penglolaannya. Saya melihatnya ini baru dalam Permendagri yang sekarang karna pada Permendagri sebelumnya belum ada, jadi saya belum terlalu detail dalam hal ini”.

Berdasarkan hasil wawancara tersebut peneliti dapat menarik kesimpulan bahwa DPKAD Aceh selaku pengelola belum sepenuhnya mengerti mengenai siklus ini sehinggan bisa dikatakan bahwa DPKAD aceh belum sesuai dengan Permendagri No.19 Tahun 2016.

13. Barang Milik Daerah Berupa Rumah Negara

Pada Permendagri No.19 Tahun 2016 Pasal 485 sampai Pasal 809 menjelaskan bahwa rumah negara merupakan barang milik daerah yang diperuntukkan sebagai tempat tinggal atau hunian dan sarana pembinaan serta menunjang pelaksanaan tugas pejabat dan/atau pegawai negeri sipil pemerintah daerah yang bersangkutan. Barang milik daerah berupa rumah negara hanya dapat digunakan sebagai tempat tinggal pejabat atau pegawai negeri sipil pemerintah daerah yang bersangkutan yang memiliki Surat Izin Penghunian (SIP).

Kasubid penatausahaan aset DPKAD Aceh melalui wawancaranya denagn peneliti mengatakan "ini baru juga dalam Permendagri, mungkin yang dimaksud di tahap ini untuk pejabat yang sudah pensiun sehingga rumah ini bisa dilakukan lelang atau dijual secara khusus karena mereka pejabat negara makanya ini diatur sendiri dalam bab tersendiri".

Berdasarkan hasil wawancara tersebut, peneliti dapat menarik kesimpulan bahwa DPKAD Aceh belum sepenuhnya paham akan tahapan ini karena
DPKAD hanya menjelaskan sebagian peraturan saja dari seluruh peraturan yang dijelaskan pada Permendagri No.19 Tahun 2016 dengan alasan bahwa ini adalah peraturan baru sehingga DPKAD Aceh belum bisa mengerti secara keseluruhan. Maka dengan ini DPKAD Aceh selaku pengelola tidak dapat dikatakan sesuai dengan Permendagri No.19 Tahun 2016 dalam melakukan pengelolaan asetnya.

14. Tuntutan Ganti Rugi

Dalam pengeloaan aset tetap pemerintah daerah, tahapan tuntutan ganti rugi adalah tahapan terakhir dari pengelolaan. Pada tahapan ini Permendagri No.19 Tahun 2016 sebagai dasar aturan dari pengelolaan aset tetap menjelaskan bahwa setiap kerugian daerah akibat kelalaian, penyalahgunaan/pelanggaran hukum atas pengelolaan barang milik daerah diselesaikan melalui tuntutan ganti rugi sesuai dengan peraturan perundang-undangan. Kemudian setiap pihak yang mengakibatkan kerugian daerah dapat dikenakan sanksi administratif dan/atau sanksi pidana sesuai dengan peraturan perundangundangan.

Wawancara peneliti dengan Kasubid penatausahaan aset DPKAD Aceh beliau mengatakan "kalau tuntutan ganti rugi biasanya dilakukan oleh tim inspektorat atau istilahnya aparatur pengawas internal pemerintah yang melakukannya dan sampai saat ini untuk kasus yang terkait masalah pengelolaan tahap ini belum ada yang bisa ditampilkan, karena ini memang sangat jarang terjadi."

Berdasarkan hasil wawancara tersebut peneliti dapat menarik kesimpulan bahwa DPKAD Aceh selaku pengelola belum pernah menemui kasus untuk tahapan ganti rugi sehingga peneliti belum dapat mengetahui apakah DPKAD sudah mengikuti Permendagri No.19 Tahun 2016 ataukah belum.

Dalam melakukan pengelolaan aset tetap daerah, DPKAD Aceh haruslah memililiki kelengkapan sumber dokumen pengelolaan aset sesuai dengan Permendagri No.19 Tahun 2016 seperti yang dijelaskan pada tabel 4.1. 
Tabel 4.1

Daftar Dokumen Sumber Pada Siklus Pengelolaan Aset Tetap

\begin{tabular}{|c|c|c|}
\hline No. & Siklus/Tahapan Pengelolaan Aset tetap & $\begin{array}{l}\text { Dokumen Sumber berdasarkan PERMENDAGRI No. } 19 \\
2016\end{array}$ \\
\hline 1 & Perencanaan kebutuhan dan penganggaran & 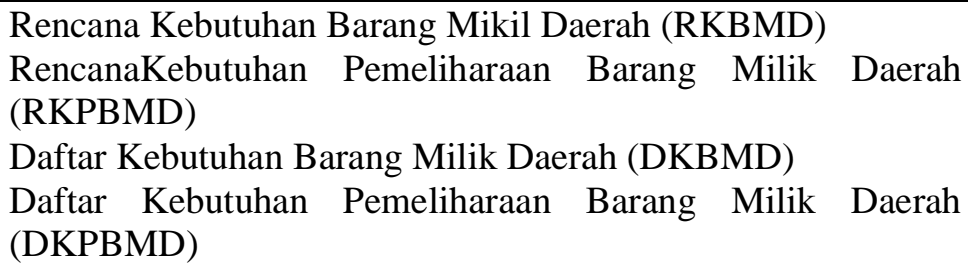 \\
\hline 2 & Pengadaan & Dokumen Pelaksanaan Anggaran \\
\hline 3 & Penggunaan & SK Kepala Daerah (Gubernur) \\
\hline 4 & Penatausahaan & $\begin{array}{l}\text { Daftar Barang Pengguna/Daftra Barang Kuasa Pengguna } \\
\text { (DBP/DBKP) Kartu Inventaris Barang (KIB) Golongan Aset } \\
\text { Tetap Tanah (A), Peralatan dan Mesin (B), G edung dan } \\
\text { Bangunan (C), Jalan, Irigasi dan Jaringan (D), Aset Tetap } \\
\text { Lainnya (E) dan Konstruksi dalam pengerjaan (F) Daftar } \\
\text { Barang Milik Daerah } \\
\text { Buku Inventaris dan Buku Induk Inventaris } \\
\text { Laporan Barang Semesteran dan Tahunan } \\
\text { Laporan Barang Milik Daerah }\end{array}$ \\
\hline 5 & Pemanfaatan & Surat Perjanjian \\
\hline 6 & Pengamanan dan pemeliharaan & $\begin{array}{l}\text { Daftar kebutuhan pemeliharaan barang } \\
\text { KIP (pengamanan) pencatatan inventaris barang }\end{array}$ \\
\hline 7 & Penilaian & SAP \\
\hline 8 & Penghapusan & Surat Keputusan Kepala Daerah \\
\hline 9 & Pemindahtanganan & Surat Keputusan Kepala Daerah \\
\hline 10 & Pembinaan, pengawasan dan pengendalian & $\begin{array}{l}\text { Pembinaan : Peraturan-peraturan } \\
\text { Pengawasan : SK \& Laporan Objek Aset Pengawasan } \\
\text { Pengendalian : Laporan Objek Aset Pengendalian }\end{array}$ \\
\hline 11 & Pemusnahan & Surat keputusan Kepala Daerah \\
\hline 12 & $\begin{array}{l}\text { Pengelolaan BMD pada SKPD yang } \\
\text { menggunakan pola pengelolaan keuangan } \\
\text { BLUD }\end{array}$ & Peraturan Perundang-undangan \\
\hline 13 & Barang milik daerah berupa rumah negara & Surat keputusan Kepala Daerah \\
\hline 14 & Tuntutan ganti rugi & Peraturan Perundang-undangan \\
\hline
\end{tabular}

Tabel diatas menjelaskan dokumen-dokumen sumber apa saja yang diperlukan dalam melakukan pengelolaan aset tetap daerah sesuai dengan Permendagri No.19 Tahun 2016. Peneliti juga melakukan pengecekan ada atau tidaknya dokumendokumen sumber tersebut di DPKAD Aceh yang dituangkan dalam tabel 4.2.

Tabel 4.2

Kelengkapan Dokumen Sumber

\begin{tabular}{|c|l|c|}
\hline No & \multicolumn{1}{|c|}{ Daftar Dokumen } & Ada $(\sqrt{ }) /$ Tidak $(\times)$ \\
\hline 1 & RKBMD & $\sqrt{ }$ \\
\hline 2 & RKPBMD & $\sqrt{ }$ \\
\hline 3 & DKBMD & $\sqrt{ }$ \\
\hline 4 & DKPBMD & $\sqrt{ }$ \\
\hline 5 & DBP/DBKP & $\sqrt{ }$ \\
\hline 6 & KIB A, B, C, D, E dan F & $\sqrt{ }$ \\
\hline 7 & Daftar Barang Milik Daerah & $\sqrt{ }$ \\
\hline 8 & Buku Inventaris dan Buku Induk Inventaris & \\
\hline
\end{tabular}




\begin{tabular}{|c|l|c|}
\hline No & \multicolumn{1}{|c|}{ Daftar Dokumen } & Ada $(\sqrt{ }) /$ Tidak $(\times)$ \\
\hline 9 & Laporan Barang Semesteran dan Tahunan (LBS dan LBT) & $\sqrt{ }$ \\
\hline 10 & Laporan Barang Milik Daerah & $\sqrt{ }$ \\
\hline 11 & Surat Perjanjian Pinjam Pakai & $\sqrt{ }$ \\
\hline 12 & Bukti Kepemilikan atas nama Pemerintah Daerah & $\sqrt{ }$ \\
\hline 13 & Daftar Hasil Pemeliharaan Barang & $\sqrt{ }$ \\
\hline 14 & Surat Keputusan Kepala Daerah & \\
\hline
\end{tabular}

Tabel diatas menjelaskan mengenai kelengkapan sumber dokumen di DPKAD Aceh. Berdasarkan hasil penelitian, peneliti masih menemukan ketidaklengkapannya sumber dokumen pengelolaan yang diantaranya adalah tidak adanya Bukti Kepemilikan atas nama Pemerintah Daerah. Hal ini membuat peneliti dapat menarik kesimpulan bahwa DPKAD Aceh dalam melakukan pengelolaan aset tetap daerah belum lah sesuai dengan aturan yang berlaku yaitu Permendagri No.19 Tahun 2016.

\section{Kesimpulan, dan saran \\ Kesimpulan}

Kesimpulan dari penelitian ini adalah:

1) Aceh merupakan salah satu daerah/wilayah yang memiliki asset tetap, contohnya berupa tanah, bangunan, gedung, kendaraan bermotr dan lain sebagainya.

2) Praktik pengelolaan aset tetap pemerintah daerah oleh DPKAD Aceh belum sepenuhnya mengikuti Permendagri No.19 Tahun 2016, seperti masih adanya beberpa dokumen sumber pengelolaan asset tetap yang DPKAD Aceh tidak di miliki.

\section{Saran}

Saran yang dapat diberikan adalah:

1. Kepada peneliti selanjutnya untuk dapat menambah bentuk proses pengeloaan aset, tidak hanya berfokus pada aset tetap daerah saja

2. Kepada DPKAD Aceh selaku pengelola untuk dapat melengkapi dokumen sumber terkait pengeloaan aset tetap daerah.

3. Kepada pemerintah untuk lebih mempelajari dan memahami Permendagri No.19 Tahun 2016 dalam pengelolaan aset tetap daerah.

\section{Daftar Pustaka}

Horngren, Charles T. Harrison, Walter T \& Bamber, Linda Smith. 2009, Akuntansi, Edisi ke-6, Jilid 1. PT Indeks, Jakarta.
Mardiasmo. 2009, Akuntansi Sektor Publik. Cetakan Keempat. Penerbit Andi, Yogyakarta.

Mulalinda, Veronika. 2014. Efektifitas Penerapan Sistem dan Prosedur Akuntansi Aset Tetap pada Dinas Pendapatan, Pengelolaan Keuangan dan Aset Daerah Kabupaten Sitaro. Universitas Sam Ratulangi, Manado. Jurnal EMBA ISSN: 23031174 Vol.2 No.1 Maret 2014. http://ejournal.unsrat.ac.id/index.php/emba/artic le/view/4169/3695. Diakses 08 April 2015. Hal 521-531.

Mustika Rasyidah.,2012. Evaluasi Penatausahaan Aset Tetap Pemerintah Kota Padang. Universitas Gajah Mada, Yogyakarta. Jurnal ABIS Magister Akuntansi FEB UGM, ISSN: 2302-1500 Vol.1 Agustus 2012. http://maksi.feb.ugm.ac.id/abis/?page=detail\&d ocID=163. Diakses 08 April 2015. Hal 1.

Nordiawan, Deddi. Ayuningtyas, Hertinti. 2010. Akuntansi Sektor Publik. Edisi Kedua. Salemba Empat, Jakarta.

Republik Indonesia. 2006. Peraturan Pemerintah Nomor 8 Tahun 2006, Tentang Pelaporan Keuangan dan Kinerja Instansi Pemerintah, Jakarta

Republik Indonesia. 2010. Peraturan Pemerintah RI No.71 Tahun 2010 Tentang Standar Akuntansi Pemerintah, Jakarta

Kementerian Dalam Negeri RI. 2013. Peraturan Menteri Dalam Negeri No.64 Tahun 2013 Tentang Penerapan Standar Akuntansi Pemerintah Berbasis Akrual Pada Pemerintah Daerah, Jakarta.

Kementerian Dalam Negeri. 2016. Peraturan Menteri Dalam Negeri No.19 Tahun 2016 Tentang Pedoman Pengelolaan Barang Milik Daerah, Jakarta.

Sugiyono. 2010. Metode Penelitian Kuantitatif, Kualitatif Dan $R \& D$. Alfabeta, Bandung. 
Tanjung, Abdul Hafis. 2010. Penatausahaan dan Akuntansi Keuangan Daerah Untuk SKPD, Edisi Kedua. Salemba Empat, Jakarta.

Yusuf, M. 2011. 8 Langkah Pengelolaan Aset Daerah Menuju Pengelolaan Keuangan Daerah Tebaik, Cetakan Kedua. Sale 